\title{
FICÇÃO 80/90: LITERATURA E EPIDEMIA DISCURSIVA ${ }^{1}$
}

\author{
80/90's fiction: literature and discursive epidemic
}

\author{
Renata Farias de Felippe \\ (D) https://orcid.org/0000-0001-9128-160X \\ Universidade Federal de Santa Maria, Departamento de Letras Vernáculas, Santa Maria, RS, \\ Brasil.97105-900 -dlvcal@gmail.com

\section{João Alcides Haetinger Esmerio} \\ (iD) https://orcid.org/0000-0002-9427-1834 \\ Universidade Federal de Santa Maria, Programa de Pós-Graduação em Letras, Santa Maria, \\ RS, Brasil.97105-900 - ppgletras@ufsm.br
}

Resumo: Este artigo pretende reanalisar parte da produção literária brasileira dos anos 1980, a partir das contradições de uma década marcada, simultaneamente, pelo arrebatamento e pelo terror. Período caracterizado pela euforia em torno da redemocratização, o decênio é também impactado pela descoberta da AIDS como pandemia, acontecimento responsável pela regulação dos corpos - ocasionada pela ênfase na prática do sexo seguro - e pela estigmatização da homossexualidade. Em Aids e suas metáforas, Susan Sontag (1989) analisa o imaginário em torno da doença, cujos desdobramentos seriam tanto o recrudescimento do preconceito contra homossexuais quanto a culpabilização das vítimas do vírus. Quando retomados e associados ao contexto brasileiro, os argumentos de Sontag (1989) assumem conotações distintas, que permitem revisitar a literatura brasileira a partir do olhar que as manifestações do período direcionaram à pandemia (recorte praticamente ignorado pela historiografia e pela crítica literária). Esse viés também permite refletir sobre a "utilidade" que a insistente exploração das metáforas ligadas à AIDS pode ter assumido. O desenvolvimento dessas propostas tomará os contos "Linda, uma história horrível" e "Depois de agosto", ambos do escritor brasileiro Caio Fernando Abreu (1988; 1995), como referências para a análise.

Palavras-chave: AIDS. Literatura brasileira dos anos 1980. Metáforas.

Abstract: This article intends to review part of the brazilian literary production of the 1980's, from the contradictions of a decade marked, simultaneously, by rapturing and terror. The decennium, period characterized by euphoria around the redemocratization, is also impacted by the emergence of AIDS, an event responsible for the redisciplination of the bodies - caused by the emphasis on the practice of safe sex - and the stigmatization of homosexuality. In Aids $e$

Esta obra está licenciada sob uma Creative Commons - Atribuição 4.0

\footnotetext{
${ }^{1}$ Expressão utilizada por Marcelo Secron Bessa (1997), no livro Histórias positivas: a literatura (des)construindo a AIDS, e retomada por Alós (2019), para tratar o fenômeno de discursivização da síndrome, sobretudo, pela literatura brasileira dos anos 1980-1990.
}

Anu. Lit., Florianópolis, v. 25, n. 1, p. 130-144, 2020. ISSNe 2175-7917 
suas metáforas, Susan Sontag (1989) analyzes the imaginary around the disease, from which the consequences would be both the recrudescence of prejudice against homosexuals and the blaming of the virus' victims. When resumed and associated to the brazilian context, Sontag's arguments assume distinct connotations that enable a revisitation of the brazilian literature from a scope directed to the pandemic by the artistic expression (which is a perspective practically ignored by the historiography and the literary studies). From this slant, it is also possible to consider the "utility" that the insistent metaphorical explorations linked to AIDS may have supported. The development of such proposals will employ the short stories "Linda, uma história horrível" and "Depois de agosto", both by the brazilian writer Caio Fernando Abreu (1988; 1995), as text corpus.

Keywords: AIDS. Brazilian 1980's literature. Metaphors.

\section{Ficção 80}

No conhecido ensaio "Ficção 80: dobradiças e vitrines", Flora Süssekind (2003) aponta as principais tendências da narrativa brasileira da década: a incidência da prosa literária fortemente entrelaçada à mimese da História - Tocaia grande (1984), de Jorge Amado e Viva o povo brasileiro (1984), de João Ubaldo Ribeiro -; a irrupção do "romance-ensaio" - Em liberdade (1981) e Stella Manhattan (1885), de Silviano Santiago -; a projeção da narrativa metamidiática - O cego e a dançarina (1980), de João Gilberto Noll. Voltados ao seu próprio tempo, os apontamentos de Süssekind (2003), surgidos no "calor da hora", não contaram com uma perspectiva suficientemente distanciada para identificar determinadas incidências temáticas na literatura da década.

Um ano após a escrita do ensaio de Süssekind - editado pela primeira vez em 1993 -, o escritor Herbert Daniel publica Alegres e irresponsáveis abacaxis americanos (1987), romance que aborda a discriminação de portadores do vírus HIV. No mesmo ano, a popular escritora Adelaide Carrara publica Socorro! Estou morrendo de AIDS, narrativa cujo teor é explicitado pelo título. Publicado em 1988, na coletânea de contos Os dragões não conhecem o paraíso, de Caio Fernando Abreu, "Linda, uma história horrível" tem como personagem um homem vitimado pela síndrome, mas será no romance Onde andará Dulce Veiga?, de $1990^{2}$, que o autor explorará de fato a jornada do protagonista portador do vírus em direção ao estabelecimento de laços afetivos e de cumplicidade.

O intervalo temporal entre a escrita e a publicação do clássico ensaio de Süssekind é também o período no qual irrompem manifestações literárias voltadas à exploração do drama dos infectados pelo vírus da AIDS, questão também exaustivamente explorada pelos meios de comunicação da época. A partir de 1987, o Ministério da Saúde, sob o governo Sarney, elege "a educação e a informação como elementos fundamentais para o controle da epidemia" (MORAIS; AMORIM, 2011, p. 98), postura que motiva o surgimento de campanhas incisivas, que adotam uma linguagem "simples e muitas vezes moralista" (MORAIS; AMORIM, 2011, p. 100). Os slogans de duas das campanhas veiculadas na época - O amor não mata e Não morra de amor -, em franca contradição, "ilustram e representam momentos de acertos e

\footnotetext{
${ }^{2}$ Cabe destacar que, anteriormente, em 1983, na novela Pela noite, há referências a AIDS, no entanto, são indiretas, diferentemente de Onde andará Dulce Veiga? (1990).
} 
controvérsias nessa trajetória composta por dramas, frustrações e conquistas" (MORAIS; AMORIM, 2011). Atônitos, os receptores assistiam a uma espécie de "guerra" discursiva:

Tanto na mídia impressa quanto na mídia televisiva houve a profusão de uma necessidade de se [sic] colocar a aids nas pautas de discussão pública, o que foi caracterizado por Marcelo Secron Bessa (1997) como uma epidemia discursiva. Colocar a aids [sic] na ordem do discurso foi, em certa medida, uma das estratégias para se atribuir sentido ao nonsense, ao desespero e ao pânico oriundos dos primeiros tempos da pandemia (ALÓS, 2019, p. 01).

Movida pela tentativa de compreender os acontecimentos, a necessidade de narrar a expansão do vírus acaba por ocasionar o surgimento de uma espécie de máquina de estigmatizações e de teorias conspiratórias.

É necessário que a doença seja nomeada, significada, descrita e narrativizada, para que se torne inteligível e, finalmente, possa ser combatida. A crise provocada pelo advento da aids [sic] gerou a necessidade de uma intensa discursivização do fenômeno: frente à falta de sentido de uma doença recémdescoberta e ainda no caminho de ser descrita pela literatura médica especializada, a mídia, os meios de comunicação, a imprensa e os jornais sensacionalistas deram a primeira resposta, isto é, uma primeira instância de significação à doença. É nesse momento que emergem alguns dos mitos mais perniciosos em torno da pandemia: o do "câncer gay", o dos "grupos de risco" e o das "teorias conspiratórias da criação de um vírus mortal" (criação atribuída às forças militares estadunidenses). (ALÓS, 2019, p. 03, grifos no original).

Se, no âmbito literário brasileiro, a exploração do tema não é frequente a ponto de constituir uma espécie de ciclo digno de nota historiográfica, ou, ainda, se a abordagem da problemática não foi vista como uma das faces proeminentes da literatura brasileira produzida nas décadas de 80 e 90, é inegável o protagonismo que a pandemia assumiu à época. Nesse sentido, reanalisar a literatura dos referidos períodos - sobretudo, as narrativas atentas à problemática da pandemia e aos seus efeitos -, como expressão surgida entre o arrebatamento e o terror, entre a euforia da redemocratização e a ameaça do vírus, nos parece fundamental. A exploração do referido ângulo traz à tona algumas interrogações inquietantes: quais os reais efeitos das campanhas incisivas de então? A ênfase dada à pandemia inibiu a abordagem de outras urgências da época? Como as manifestações literárias atentas aos efeitos da pandemia podem ser ressignificadas?

\section{Metáforas da pandemia}

A AIDS, termo originário do inglês Acquired Immunodeficiency Syndrome e traduzido para o português como Síndrome da Imunodeficiência Adquirida (SIDA), foi reconhecida como doença mundial a partir da década de 80 , momento em que sua expansão teve grande repercussão no Brasil. Era um período em que pouco se sabia sobre a doença, que chegou a ser considerada a pior e mais terrível do século. Denominada à época como a "peste-gay", o vírus 
levou à morte jovens artistas brasileiros, como o cantor Cazuza ${ }^{3}$, em 1990, o líder da banda Legião Urbana, o músico Renato Russo, em 1996 e, no mesmo ano, o escritor, jornalista e dramaturgo Caio Fernando Abreu.

Desde 1996, no Brasil, os portadores do HIV (Vírus da Imunodeficiência Humana) e acometidos pela AIDS têm garantido pela Lei $n^{\circ}$ 9.313/96 o acesso gratuito a toda a medicação necessária a seu tratamento, através do Sistema Único de Saúde (SUS) (BRASIL, 1996), o que representou grande avanço no combate à síndrome. A Lei que ajuda e que dá suporte, porém, pode ser a mesma Lei que segrega e estigmatiza. Um exemplo real disso está presente no Artigo 64, inciso IV, portaria 158/2016, do Ministério da Saúde, que considera “inaptos" para doar sangue por 12 meses homens que tiveram relações sexuais com outros homens, bem como as parceiras sexuais desses (BRASIL, 2016). Este é um exemplo que fere a sexualidade dos indivíduos, pois respalda o imaginário de estigmatização movido pela associação entre homossexualidade e AIDS. Determinação que reforça a ideia de que ainda há grupos de risco, no caso, os homossexuais masculinos, o estigma recai também sobre homens heterossexuais que tiveram relações com outros homens, bem como sobre as suas parceiras sexuais. Determinações como essas julgam a partir do elemento vital, o sangue, e segregam o "bom" do "ruim", sendo as relações sexuais entre homens explicitamente colocadas no âmbito negativo e potencialmente pernicioso.

Exaustivamente explorada midiaticamente, a expansão da síndrome não apenas modificou os comportamentos sexuais - a necessidade de disciplinar os corpos através da prática preventiva passa a ser fundamental —, mas também agudizou o preconceito voltado, sobretudo, contra homossexuais masculinos. Se os anos 1970 foram marcados por políticas identitárias unificadoras e assimilacionistas que admitiam a integração dos homossexuais, o surgimento da doença na década posterior, acaba por recrudescer a homofobia latente.

No Brasil dos anos 1980, a abertura política e a posterior redemocratização originam uma espécie de euforia abruptamente interrompida pelo temor em torno da "peste gay" ou do "câncer gay", denominações que explicitam a utilização de "fórmulas discursivas oportunistas que associavam a infecção pelo HIV a um conjecturado castigo pela vida pecaminosa" (ALÓS, 2019).

Em “AIDS e suas metáforas" (1988), ensaio que dá continuidade ao texto "Doença como metáfora” (1978), Susan Sontag define o que entende por metáfora, visão que vai ao encontro de uma concepção aristotélica: "dar a uma coisa o nome de outra”, utilização de um termo para explicar outro. Segundo a autora: "sem dúvida, é impossível pensar sem metáforas. Mas isso não impede que haja algumas metáforas que seria bom evitar, ou tentar retirar de circulação" (SONTAG, 1989, p. 09).

\footnotetext{
${ }^{3}$ Um dos contos a ser analisado, "Linda, uma história horrível" (1988), de Caio Fernando Abreu, tem como epígrafe os seguintes versos da canção "Só as mães são felizes", de Cazuza: "Você nunca ouviu falar em maldição/ nunca viu um milagre/ nunca chorou sozinha num banheiro sujo/ nem nunca quis ver a face de Deus". Os sentidos de "maldição" e de "sujidade", abordados pelo conto, são teorizados por Sontag no texto "AIDS e suas metáforas", no original "AIDS and its Metaphors", de 1988, sendo a versão traduzida ao português publicada em 1889, no Brasil. Ensaio cujos preceitos norteiam a presente análise.
} 
Na sequência, a ensaísta apresenta a definição geral do termo AIDS, como estado clínico ocasionado por outras doenças (as chamadas "infecções oportunistas"), e não como uma doença. Quanto à transmissão, Sontag (1989) estabelece uma relação de analogia entre o contágio do vírus HIV e a metáfora da poluição, já que ambos os processos estão associados às ideias de "sujeira", de "impureza" (SONTAG, 1989).

Outra metáfora destacada pela ensaísta é a da invasão, associação que remete exército de doenças oportunistas responsáveis pelos óbitos dos portadores do HIV. Também presentes no sistema imunológico sadio, no caso dos acometidos pela síndrome, tais doenças acabam por debilitá-los e enfraquecê-los de forma aguda ou mesmo letal (SONTAG, 1989). Doenças antes consideradas raras, como o Sarcoma de Kaposi e a pneumonia, são as doenças mais comuns entre os acometidos pela AIDS. Há ainda uma gama de sintomas que afetam, incapacitam, desfiguram e humilham diretamente o paciente, a ponto de torná-lo incapaz de controlar ou de atender às suas necessidades mais básicas (SONTAG, 1989).

Atenta também à questão da culpabilidade, associada à vergonha, Sontag (1989) argumenta que contrair o vírus equivale a pertencer a um "determinado grupo de risco" ou, como ela diz, a uma "comunidade de párias", de excluídos do convívio social. A associação do doente ao denominado "grupo de risco" acaba por ligá-lo aos excessos sexuais e, consequentemente, por responsabilizá-lo pelo contágio (SONTAG, 1989).

Ainda, Sontag (1989) disserta sobre a última e mais importante metáfora para esse estudo: a metáfora da peste. De acordo com a autora, a "peste" é a principal metáfora através da qual a epidemia da AIDS é compreendida. E por causa da AIDS, a ideia "generalizada, embora absurda, de que o câncer é uma epidemia, até mesmo uma peste, parece estar desaparecendo: a AIDS banalizou o câncer" (SONTAG, 1989, p. 53). Essa concepção de "peste" remete aos termos "flagelo", "calamidade", sentidos ligados à ideia de "mal coletivo", como se determinadas doenças fossem alertas para práticas reprováveis da coletividade.

A partir disso, Sontag (1989) coloca a AIDS no mesmo nível de doenças consideradas epidêmicas, pestilentas, reiterando a questão da culpabilidade, pois as doenças coletivas são encaradas como castigos impostos:

A peste é invariavelmente encarada como uma condenação da sociedade, e quando a metaforização da AIDS a transforma numa condenação, as pessoas acostumam-se à idéia de que a doença inevitavelmente se espalhará por todo o mundo. Essa é a utilização tradicional das doenças sexualmente transmissíveis: apresentá-las como castigos impostos não apenas a indivíduos, mas também a todo um grupo ("licenciosidade geral"). (SONTAG, 1989, p. $64)$.

Esse discurso de culpa reforçado pelas metáforas da AIDS reflete no medo pela sexualidade. Sontag (1989) disserta que a AIDS estimula um temor que acaba por recair sobre todas as formas de sexualidade, quer sejam monogâmicas, promíscuas, heterossexuais, já que o sangue e os fluidos sexuais são vistos como ameaçadores. As representações negativas do portador do vírus, portanto, não só o estigmatizam como o ultrapassam, e, nesse sentido, segundo a ensaísta, elas têm desdobramentos tão prejudiciais quanto a doença propriamente 
dita. A ênfase sobre "um cenário de enfermidade pode expressar a suspensão da moral e dos afetos, algo que prevê o instalar dos desafetos e o domínio do comportamento imoral/amoral sobre o Outro" (MARKENDORF; FELIPPE, 2018, p. 310), o que agudiza a vulnerabilidade dos acometidos pela síndrome.

As considerações permitem entrever o impacto que enfermidade exerceu sobre o imaginário, sobre os discursos e também sobre os afetos nas décadas de 80 e 90 . A onipresença da problemática e dos seus desdobramentos pode também oferecer um ângulo relevante para a análise da literatura brasileira produzida no período posterior à redemocratização. Entre tais produções está a ficção de Caio Fernando Abreu, parte dela atenta aos temores e à estigmatização em torno da síndrome.

\section{A vida que grita}

A vida grita. E a luta, continua.

(ABREU, O Estado de S. Paulo, 18/09/1994)

Caio Fernando Abreu é contemporâneo da geração que passa pelo golpe militar de abril de 1964, pela repressão dos movimentos estudantis de 1968, pela cassação dos direitos políticos com o AI-5, pela tortura. Concomitante à repressão política e expressiva, no período, ocorre um surto industrial e modernizador no país, que intensificou a produção de bens de consumo. Tal processo, indiretamente, favoreceria também segmentos marginalizados da cultura brasileira, já que o acesso e o consumo dos produtos da indústria cultural forneceriam aos grupos historicamente alijados as "novidades" pelas quais ansiavam.

Abreu vivenciou vários dos períodos mais significativos do Brasil da segunda metade do século passado, faleceu no dia 25 de fevereiro de 1996, em Porto Alegre, vitimado por uma pneumonia aguda, decorrente do vírus HIV. A literatura, a vida e a morte do escritor, portanto, não poderiam ser mais sintomáticas de uma época.

"Linda, uma história horrível" é o primeiro dos 13 contos compilados no livro Os dragões não conhecem o paraíso, de Caio Fernando Abreu (1988), coletânea que, em 1989, foi agraciada com o Prêmio Jabuti. $\mathrm{O}$ enredo do conto trata do regresso inesperado de um filho à casa de sua mãe. Filho e mãe são personagens anônimas, apresentadas por um narrador em terceira pessoa.

- Tu não avisou que vinha - ela resmungou no seu jeito azedo, que antigamente ele não compreendia. Mas agora, tantos anos depois, aprendera a traduzir como que saudade, seja-benvindo, que-bom-ver-você ou qualquer coisa assim. Mais carinhosa, embora inábil.

Abraçou-a, desajeitado. Não era um hábito, contatos, afagos. Afundou tonto, rápido, naquele cheiro conhecido - cigarro, cebola, cachorro, sabonete, creme de beleza e carne velha, sozinha há anos. Segurando-o pelas duas orelhas, como de costume, ela o beijou na testa. Depois foi puxando-o pela mão, para dentro (ABREU, 1988, p. 14).

Este fragmento abarca não só o momento da chegada do filho, mas também a questão do 
narrador. O regresso do filho ocorre de maneira inesperada, como fica claro pela fala da mãe: "tu não avisou que vinha", quando a mãe o recepciona e logo vai "puxando-o pela mão para dentro" de casa. Não se sabe exatamente quanto tempo o filho ficou fora da casa materna, mas foi bastante tempo, o que fica evidenciado pela marcação temporal "mas agora tantos anos depois". O narrador descreve essas ações em um plano privilegiado, o que leva a crer que o narrador seja o filho distanciado pela memória: ele conhece o jeito das personagens, no caso da mãe, o "jeito azedo" que a personagem expressa pelo modo de falar. Ele também sabe o que o filho está pensando sobre o jeito da mãe, enquanto ela o recebe: "antigamente ele não compreendia. Mas agora, tantos anos depois aprendera a traduzir como saudade[...]".

No conto, a AIDS não aparece de maneira explícita, mas indicada por pistas dadas através da narração, dos elementos que compõem o espaço. Essas inferências são dadas principalmente entre as falas das personagens. Depois ser recepcionado pela mãe, filho e progenitora têm uma conversa. Após um longo hiato, o filho retorna à casa da família e a mãe tem interesse em saber como ele está, bem como o motivo da inesperada visita. Sentados, frente a frente dialogam:

- Tu estás mais magro - ela observou. Parecia preocupada. - Muito mais magro.

- É o cabelo - ele disse. Passou a mão pela cabeça quase raspada. E a barba de três dias.

- É a idade. Quase quarenta anos. - Apagou o cigarro. Tossiu. - E essa tosse de cachorro?

- Cigarro, mãe. Poluição.

Levantou os olhos, pela primeira vez olhou direto nos olhos dela. Ela também olhava direto nos olhos dele. Verde demasiado por trás das lentes dos óculos, subitamente muito atentos. Ele pensou: é agora, nesta contramão. ${ }^{*}$ Quase falou. Mas ela piscou primeiro. Desviou os olhos para baixo da mesa, segurou com cuidado a cadela sarnenta e a trouxe até o colo.

- Mas vai tudo bem?

- Tudo, mãe.

- Trabalho?

Ele fez que sim. Ela acariciou as orelhas sem pelo da cadela. Depois olhou outra vez direto para ele:

- Saúde? Diz que tem umas doenças novas aí, vi na tevê. Umas pestes.

- Graças a Deus - ele cortou. Acendeu outro cigarro, as mãos tremiam um pouco. - E a dona Alzira, firme?

A ponta apagada do cigarro entre os dedos amarelos, ela estava recostada na cadeira. Olhos apertados, como se visse por trás dele. No tempo, não no espaço. [...] Ela suspirou, sacudiu os ombros:

- Coitada. Mais esclerosada do que eu. (ABREU, 1988, p. 18).

No excerto percebe-se que para cada pergunta feita pela mãe o filho dá uma resposta trivial. Ela, sentada em frente a ele, assume um papel quase que de médico, pois constrói uma análise dos caracteres perceptíveis a olho nu: magreza, queda de cabelo, tosse. O "exame" materno direciona o conto para um ápice que não se materializa: a revelação do filho sobre a sua condição terminal. $\mathrm{O}$ personagem chega a mentalizar o momento da revelação naquela

\footnotetext{
${ }^{4}$ Grifo do autor. (*) Cita "Mocidade independente", de Ana Cristina César, A Teus Pés.
} 
"contramão", mas hesita. A conversa continua. As perguntas da mãe passam a ser mais objetivas: "Mas vai tudo bem?". E as respostas do filho também: “Tudo, mãe”. Só que já não há mais interesse nessa conversa, por parte do filho, a ponto de ele não mais responder, limitando-se a concordar, com gestos: "Trabalho? / Ele fez que sim". Mesmo assim, a mãe continua, e a próxima pergunta causa desconforto nele, ele fica nervoso e muda de assunto: "Saúde? [...] / Graças a Deus - ele cortou. Acendeu outro cigarro, as mãos tremiam um pouco./ - E a dona Alzira, firme?". A atitude evasiva do filho demonstra que, no que se refere à saúde, ele escondia algo. Mesmo que a enfermidade não seja explicitamente nomeada, indícios apontam para a famigerada "peste", como é possível verificar no fragmento a seguir:

Ele abriu os olhos. Como depois de uma vertigem, percebeu-se a olhar
fixamente para o grande espelho da sala. No fundo do espelho na parede da
sala de uma casa antiga, numa cidade provinciana, localizou a sombra de um
homem magro demais, cabelos quase raspados, olhos assustados feito os de
uma criança. Colocou a garrafa sobre a mesa, tirou o casaco.
Suava muito. Jogou o casaco na guarda de uma cadeira. E começou a
desabotoar a camisa manchada de suor e uísque.
Um por um, foi abrindo os botões. Acendeu a luz do abajur, para que a sala
ficasse mais clara quando, sem camisa começou a acariciar as manchas
púrpura, da cor antiga do tapete na escada - agora, que cor? -, espalhadas
embaixo dos pelos do peito. Na ponta dos dedos, tocou o pescoço. (ABREU,
1988, p. 21-22).

Diante do espelho, o personagem esboça o reconhecimento de si, identificando no próprio rosto "os olhos assustados feito os de uma criança" e o suor excessivo, condições que podem refletir um duplo temor: o da própria doença, que toma o corpo do protagonista, e o de admitir à mãe idosa a "culpa" pela enfermidade que o acomete. As "manchas púrpura, espalhadas embaixo dos pelos do peito" são os indícios mais reveladores da atuação da AIDS, já que as "manchas púrpura" são sintomas do Sarcoma de Kaposi. Outro indício da enfermidade acaba por estabelecer uma espécie de relação de espelhamento entre o filho e Linda, a cadela de estimação mencionada no título do conto.

Ao caracterizar a tosse do filho como "de cachorro", a mãe tem "a cadela sarnenta", ironicamente chamada de Linda, no colo. A presença da cadela é também uma inferência, um comparativo implícito para o estado degradante em que o filho se encontra, pois, além da sarna (que metaforicamente pode ser associada ao Sarcoma de Kaposi), a cadela apresenta queda de pelo e cegueira. Segundo a mãe, Linda "só sabe dormir, comer e cagar esperando a morte" (ABREU, 1988, p. 14), condição que parece projetar a agonia do protagonista enfermo.

O espaço da narrativa também remete ao estado de degradação do filho, pois é à casa da mãe que regressa, a fim de abrigar-se. A casa, um ambiente fechado, é suja e deteriorada: "Manchadas de gordura, as paredes da cozinha. A pequena janela basculante, vidro quebrado" (ABREU, 1988, p. 15). O filho, magro demais, com pouco cabelo, decadente, assemelha-se ao espaço de paredes sujas de gordura, que parecem refletir a pele do personagem, tomada pelas manchas do Sarcoma de Kaposi.

Todos os caracteres próprios ao filho remetem às metáforas da AIDS apontadas por 
Sontag (1988), comparações implícitas ligadas à poluição, à invasão, à peste, construções que acabam por imputar a culpabilidade ao infectado.

Quanto à metáfora da poluição, ela está presente no filho não apenas em seu aspecto exterior, materializada pelas suas manchas de pele (que, por sua vez, remetem às doenças oportunistas): ela circula em suas veias, está em seu sangue "sujo", "poluído", capaz de contaminar, de "invadir" outras pessoas. Além disso, o próprio personagem, ao tentar justificar a tosse excessiva, afirma que a sua causa é o cigarro e a poluição.

A metáfora da peste, presente no conto, é, inclusive, nomeada, quando mãe e filho estão dialogando e ela pergunta sobre o estado de saúde do personagem: “- Saúde? Diz que tem umas doenças novas aí, vi na tevê. Umas pestes" (ABREU, 1988, p. 18, grifo no original). Outra referência ao mal coletivo surge quando o filho adentra na cozinha e lê em uma folha de jornal, usada pela mãe para cobrir um vidro quebrado: "País mergulha no caos, na doença e na miséria" (ABREU, 1989, p. 15, grifos no original). "Caos e doença" estão no mesmo campo semântico da peste. A passagem metaforiza todo um imaginário de males coletivos que foram insistentemente propagados pelos veículos midiáticos de então, reforçando o caráter letal atribuído à síndrome. Encarada como uma epidemia, como uma situação alarmante, a responsabilidade pela expansão da "doença" recaía, principalmente, sobre os homossexuais, os “culpados" pelo caos.

A sexualidade do filho é também inferida através do diálogo que ele estabelece com a mãe: “- E o Beto? -, ela perguntou de repente" / [...] "- Tá lá, mãe. Vivendo a vida dele” (ABREU, 1988, p. 19). Nesse fragmento entra a figura do "Beto", indiretamente, colocado na posição de genro, o que fica evidenciado quando a mãe relata ao filho uma conversa que teve com Elzinha, sua outra filha: "Um moço tão fino, aquilo é que é moço fino. Eu falei pra Elzinha, bem na cara do Pedro. Para ele tomar como indireta mesmo, eu disse bem alto, bem assim" (ABREU, 1988, p. 20). Aprovado pela mãe, Beto é, por outro lado, eufemisticamente por ela denominado como "amigo" do personagem: "- Isso que é amigo, meu filho. Até meio parecido contigo, eu fiquei pensando. Parecem irmãos. Mesma altura, mesmo jeito, mesmo" (ABREU, 1988, p. 19). O filho, porém, revela não possuir mais uma relação com Beto: “- A gente não se vê faz algum tempo, mãe. / [...] - E por quê? / [...] - Mãe - ele começou. A voz tremia. - Mãe, é tão difícil - repetiu. E não disse mais nada" (ABREU, 1988, p. 19). Possivelmente motivado pela doença, o afastamento entre o personagem e Beto reforça a solidão, a situação de quase abandono do personagem. O seu sentimento de desamparo, ligado à estigmatização provocada pela doença, estabelece uma espécie de barreira entre mãe e filho, obstáculo que ele não consegue transpor. Assim, o regresso do filho à casa materna é mais do que uma simples visita, é um isolamento, uma busca por refúgio, já que tudo estava lá como ele havia deixado quando partiu: “- Teu quarto continua igual lá em cima. [...] Tem lençol limpo no armário do banheiro." (ABREU, 1988, p. 21). O quarto mantido, os lençóis limpos indicam o zelo, a espera materna pelo retorno do filho, ainda que em certos momentos as falas da idosa revelem a mágoa pelo distanciamento do personagem.

Debilitado, o filho escolhe a casa da mãe, em uma cidade interiorana, Passo da 
Guanxuma, para abrigar-se, refugiar-se, não da doença, que, irremediavelmente o acompanhará, mas da sociedade que o acusa, que o vê como corporificação de todas as metáforas degradantes e depreciativas associadas à condição de infectado.

O segundo conto analisado, "Depois de agosto" é o último dos 24 contos que compõem a seleta Ovelhas negras, de Caio Fernando Abreu, livro publicado em 1995, um ano antes do falecimento do autor. Dividido em onze segmentos, sendo um epílogo e dez partes ("Primavera", "Jade", "Anunciação", "Oriente", "Soneto", "Fuga", "Espelho", "Valsa", "Finais", "Bolero"), na narrativa cada divisão compreende uma cena, um momento, protagonizado por "ele". Assim como em "Linda, uma história horrível”, em "Depois de agosto" o personagem central não é nomeado e o narrador é onisciente:

Naquela manhã de agosto, era tarde demais. Foi a primeira coisa que ele pensou ao cruzar os portões do hospital apoiado náufrago nos ombros dos dois amigos. Anjos da guarda, um de cada lado. Enumerou: tarde demais para a alegria, tarde demais para o amor, para a saúde, para a própria vida, repetia e repetia para dentro sem dizer nada, tentando não olhar os reflexos do sol cinza nos túmulos do outro lado da avenida Dr. Arnaldo. Tentando não ver os túmulos, mas sim a vida louca dos túneis e viadutos desaguando na Paulista, experimentava um riso novo. Pé ante pé, um pouco para não assustar os amigos, um pouco porque não deixava de ser engraçado estar de volta à vertigem metálica daquela cidade à qual, há mais de mês, deixara de pertencer (ABREU, 2010, p. 126).

À semelhança do conto de 1988, a síndrome não é nomeada em "Depois de agosto", porém o sentimento de "tarde demais" (para a "alegria", o "amor", a "saúde", a "vida") remete à enfermidade, associação que o prólogo do conto parece reforçar: "Talvez seja um tanto cifrada, mas para um bom leitor certo mistério nunca impede a compreensão" (ABREU, 2010, p. 121, grifos no original). Entre amigos, entre pares, o protagonista de "Depois de agosto" não tem nada a esconder, como revela o fragmento: "embora os três e todos os outros que já sabiam ou viriam a saber, pois ele tinha o orgulho de nada esconder, tentassem suaves disfarçar, todos sabiam que ele sabia que tinha ficado tarde demais" (ABREU, 2010, p. 126). O "orgulho de nada esconder", o fato de os amigos auxiliarem o protagonista, evidencia a solidariedade entre semelhantes, único apoio de que o personagem parece dispor ${ }^{5}$. A expressão "tarde demais", repetida doze vezes no conto, reitera a impossibilidade de cura e revela a tragicidade que atravessa a narrativa, a qual é parcialmente "encoberta” pela linguagem ágil adotada na passagem: "Dividia-se entre natações, vitaminas, trabalho, sono e punhetas loucas para não enlouquecer de tesão e de terror. Os pulmões, falaram, o coração. Retrovírus, Plutão em Sagitário, alcaçuz, zidovudina e Rá!” (ABREU, 2010, p. 126).

Zidovudina, ou AZT, é o fármaco utilizado como antirretroviral para combater um tipo

\footnotetext{
${ }^{5}$ No artigo "Carga zerada: HIV/AIDS, discurso, desgaste, cultura", Emerson da Cruz Inácio (2016) trata da "conformação de uma outra Estética das Amizades, baseadas na ajuda, na solidariedade" desenvolvidas entre acometidos pelo vírus e seus pares. Essa estética "potencializa por um lado o abandono dos indivíduos diante da doença, mas, por outro, denota a premente necessidade de estabelecimento de laços de afeto que transcendessem as noites de sexo" (INÁCIO, 2016, p. 489).
} 
específico de pneumonia comum entre os portadores do vírus. O alcaçuz, raiz utilizada pela medicina natural no combate à tosse, também pode ser associado à pneumonia. Já a referência ao retrovírus - vírus que, ao duplicar-se, contamina as células boas -, é mencionado no fragmento como se fosse um componente do horóscopo ("Retrovírus, Plutão em Sagitário"), o que "abranda" as conotações do termo. O acúmulo de imagens e de inferências presente no fragmento não só remete ao uso dos medicamentos para tratar a doença, como também direciona à ideia de que o tratamento da enfermidade consome seu tempo restante de vida. $\mathrm{A}$ série de menções alude à agilidade e ao dinamismo, o que parece encobrir o sentido trágico que permeia a narrativa.

Diferentemente de "Linda", em "Depois de agosto" a sexualidade do personagem é explicitada pela menção ao "outro", o amante, que se recusa a abandonar o protagonista, o que causa perplexidade no último:

Mas se o outro, cuernos, se o outro, como todos, sabia perfeitamente de sua situação: como se atrevia? por que te atreves, se não podemos ser amigos simplesmente, cantarolou distraído. Piedade, suicídio, sedução, hot voodoo, melodrama. Pois se desde agosto tornara-se o tão impuro que sequer os leprosos de Cartago ousariam tocá-lo, ele, o mais sarnento de todos os cães do beco mais sujo de Nova Délhi (ABREU, 2010, p. 123-124, grifos no original).

Esse fragmento pode ser associado diretamente às metáforas da AIDS e às suas conotações ("poluição", "peste" e a consequente relação sexualidade/culpabilidade). A perspectiva do personagem indica que ele seria "tão impuro que sequer os leprosos de Cartago ousariam tocá-lo" e "o mais sarnento de todos os cães do beco mais sujo de Nova Délhi". Esse perfil "leproso", "sarnento", enfim, "impuro" está associado às metáforas de poluição e da peste ligadas ao imaginário sobre a AIDS, o que aporta, igualmente, a ideia de sujidade, de incorreção. Segundo o personagem infectado, é tarde demais para amar. Autoimposta, a impossibilidade de amor pode ser diretamente associada à culpa. Fechado ao amor, o personagem recorda, nostalgicamente, momentos de sua vida pregressa, quando ainda podia cultivar hábitos prazerosos, incompatíveis com a sua condição de doente terminal. Plástica e detalhada, na passagem a seguir o personagem expõe a sua visão particular de "paraíso", que inclui a total admissão de sua sexualidade:

Ah, sentar na mesa de um bar para beber nem que fosse água brahma light
cerpa sem álcool (e tão chegado fora aos conhaques) falando bem ou mal de
qualquer filme, qualquer livro, qualquer ser, enquanto navios pespontavam a
bainha verde do horizonte e rapazes morenos musculosos jogassem
eternamente futebol na areia da praia com suas sungas coloridas protegendo
crespos pentelhos suados, peludas bolas salgadas. (ABREU, 2010, p. 123,
grifos nossos).

No que diz respeito às metáforas da invasão associadas à síndrome, o reconhecimento do Sarcoma de Kaposi também é referido no conto quando o personagem se olha no espelho: "Meio fingindo que não, pela primeira vez desde agosto olhou-se disfarçado no espelho do hall do hotel. As marcas tinham desaparecido. Um tanto magro [...]" (ABREU, 2002, p. 117). No 
fragmento, a referência temporal ("desde agosto") sugere o momento em que o personagem toma conhecimento da sua condição de portador e enfermo. A marca temporal corresponde ao título do conto e ao marco divisor da existência do protagonista.

Por meio de um sonho, o personagem recorda que já havia conversado com o "outro", sobre a sua condição de infectado. A passagem que trata sobre o sonho acaba por revelar ao leitor que ambos os personagens estão na mesma situação. A condição comum parece atenuar o isolamento dos amantes, bem como justificar a relação de empatia e de afeto por parte do "outro":

Ele sentou. O outro perguntou:

- Nosso amigo te contou?

$-\mathrm{O}$ quê? O outro pegou na mão dele. A fina, leve, fresca.

- Que eu também.

Ele não entendia.

- Que eu também - o outro repetiu.

O ruído dos carros nas curvas de Ipanema, a lua nova sobre a lagoa. E feito um choque elétrico, raio de Iansã, de repente entendeu. Tudo.

- Você também - disse, branco.

- Sim - o outro disse sim (ABREU, 2010, p. 126).

Os amantes se separam, cada um tem que seguir seu rumo, mas o distanciamento entre eles não é exatamente uma ruptura: as incertezas quanto ao futuro é que os apartam um do outro. É "tarde demais" para uma vida comum.

Na manhã de Iemanjá, ele jogou rosas brancas na sétima onda, depois partiu sozinho. Não fizeram planos. Talvez um voltasse, talvez o outro fosse. Talvez um viajasse, talvez outro fugisse. Talvez trocassem cartas, telefonemas noturnos, dominicais, cristais e contas por sedex, que ambos eram meio bruxos, meio ciganos, assim meio babalaôs. Talvez ficassem curados, ao mesmo tempo ou não. Talvez algum partisse, outro ficasse. Talvez um perdesse peso, o outro ficasse cego. Talvez não se vissem nunca mais, com olhos daqui pelo menos, talvez enlouquecessem de amor e mudassem um para a cidade do outro [...] (ABREU, 2010, p. 127).

O fragmento explicita o que o protagonista espera do "outro", que é também o seu reflexo, o seu duplo. Colocada em suspenso, a relação entre eles esbarra no "tarde demais para a alegria, tarde demais para o amor, para a saúde, para a própria vida” (ABREU, 2010, p. 126) condição a qual os vitimados pelo vírus estavam, fatalmente, restritos.

A ausência de nomes próprios em ambos os contos de Abreu (apenas a cadela Linda é nomeada) sugere uma espécie de despersonalização, como se cada personagem representasse diferentes facetas de um drama que afligiu e/ou vitimou toda uma geração.

\section{Considerações finais}

As questões levantadas e as análises pretendem delinear o modo como as manifestações literárias brasileiras dos anos 80 e 90 responderam à epidemia discursiva que lançou sobre os denominados "grupos de risco", especialmente, sobre os homens gays, o peso de todos os males. 
Mesmo que de forma episódica, se comparada à exploração "epidêmica" operada pelos veículos midiáticos, as produções de escritores como Herbert Daniel, Caio Fernando Abreu, Alberto Guzik e Valéria Polizzi responderam ficcionalmente à estigmatização dos acometidos pela síndrome ao visibilizarem, através das personagens, os conflitos, os afetos, as demandas, as buscas por amparo enfrentadas por aqueles que sofreram os sintomas da síndrome e os males da incompreensão. Ao contrário dos escritores seus contemporâneos, que incursionaram pelo romance histórico, pelo romance-ensaio ou pela estratégia metamidiática e que, assim, distanciaram-se da guerra de discursos referida, Abreu, Herbert, Guznik, Polizzi atentaram à "vida que grita", convertendo-a em ficção.

Nos casos de Herbert e Abreu a consideração de suas respectivas resistências literárias à epidemia discursiva leva-nos a questionar o que motivou a última e o que, talvez indiretamente, ela "acobertou" ou (no mínimo) adiou. O esboço de resposta a esse questionamento talvez passe pelas peculiaridades do próprio período de redemocratização brasileiro.

Cercada por instabilidades, ameaças e negociatas, a volta do Brasil à "democracia" é inaugurada por eleições presidenciais indiretas e seguida pelo silêncio - ou pelo silenciamento? - referente aos crimes da recém encerrada ditadura militar. Assim, a euforia por um "novo" começo encobre a necessidade de manutenção da memória. Dois anos depois das eleições indiretas, durante o governo Sarney, o surgimento da pandemia recebe ostensiva atenção midiática e passa a ser mote de campanhas públicas. Indiretamente, a exploração da "peste"6 e a culpabilização de seus portadores parece ter contribuído para o adiamento de debates fundamentais que, mesmo nos dias de hoje, permanecem parcialmente discutidos.

\section{Referências}

ABREU, Caio Fernando. Linda, uma história horrível. In: ABREU, Caio Fernando. Os dragões não conhecem o paraíso. São Paulo: Cia. Das Letras, 1988. p. 13-22.

ABREU, Caio Fernando. Depois de agosto. In: ABREU, Caio Fernando. Ovelhas negras. Porto Alegre: L\&PM, 2010, p. 121-127.

ALÓS, Anselmo Peres. Corpo infectado/corpus infectado: aids, narrativa e metáforas oportunistas. Revista Estudos Feministas, Florianópolis, v. 27, n. 3, e57771, 2019. Disponível em: https://periodicos.ufsc.br/index.php/ref/article/view/1806-9584-2019v27n357771/42081. Acesso em: 27/04/2020.

BRASIL. Lei n. 9.313, de 13 de novembro de 1996, que dispõe sobre a distribuição gratuita de medicamentos aos portadores do HIV e doentes de AIDS. Diário Oficial da União. Poder Executivo, Brasília, DF, 13 de nov. 1996.

\footnotetext{
${ }^{6}$ Convém destacar que a possibilidade apontada não questiona a importância das políticas públicas de prevenção e de tratamento do vírus, mas o tom frequentemente alarmista adotado pelas campanhas governamentais e pelos meios de comunicação, sobretudo, ao longo da década de 80.
} 
BRASIL. Ministério da Saúde. Portaria n. 158, de 4 de fevereiro de 2016, que redefine o regulamento técnico de procedimentos hemoterápicos. Diário Oficial da União. Brasília, DF, 04 de fev. 2016.

INÁCIO, Emerson da Cruz. Carga zerada: HIV/AIDS, discurso, desgaste, cultura. Via Atlântica, São Paulo, n. 29, p. 479-505, 2016. Disponível em: http://www.revistas.usp.br/ viaatlantica/article/view/118885. Acesso em: 06/09/2019.

MARKENDORF, Marcio; FELIPPE, Renata de. Ficções da peste: esboço para um estudo do imaginário ficcional das doenças. Scripta Uniandrade, Curitiba, v.16, n. 11, p. 309-331, 2018. Disponível

em: https://uniandrade.br/revistauniandrade/index.php/ScriptaUniandrade/article/view/87 2/828. Acesso em: 27/04/2020.

MORAIS, Preciliana de; AMORIM, Rosendo de. Políticas públicas de saúde e campanhas de prevenção à AIDS: resgatando algumas controvérsias enfrentadas nas décadas de 80 e 90 . Tempo da Ciência. Cascavel, v.18, n. 35, p. 95-113, 2011. Disponível em: http://erevista.unioeste.br/index.php/tempodaciencia/article/view/9003/6595. Acesso em 27/04/2020.

SONTAG, Susan. AIDS e suas metáforas. Trad. de Michael Henry Heim. São Paulo: Companhia das Letras, 1989.

SÜSSEKIND, Flora. Ficção 80: dobradiças e vitrines. In: SÜSSEKIND, Flora. Papéis colados. Rio de Janeiro: Ed. UFRJ, 2003. p. 257-272.

\section{NOTAS DE AUTORIA}

Renata Farias de Felippe (renafelippe@yahoo.com.br) é doutora em Teoria Literária (2009) e Mestre em Literatura Brasileira (2003) pela Universidade Federal de Santa Catarina, graduada em Letras/Português pela Fundação Universidade Federal do Rio Grande (2000). Professora Associada (nível 1) da Universidade Federal de Santa Maria, realizou pós-doutorado no Programa de Literatura e Cultura da Universidade Federal da Bahia (2017).

João Alcides Haetinger Esmerio (joaoesmerio@hotmail.com) é graduado em Letras Português Bacharelado pela Universidade Federal de Santa Maria (2017). Mestrando em Estudos Literários no Programa de Pós-Graduação em Letras da Universidade Federal de Santa Maria. Bolsista CAPES. Tem experiência na área de Letras, com ênfase em Letras, Linguística e Literaturas em Língua Portuguesa.

Como citar esse artigo de acordo com as normas da revista

FELIPPE, Renata Farias de; ESMERIO, João Alcides Haetinger. Ficção 80/90: literatura e epidemia discursiva. Anuário de Literatura, Florianópolis, v. 25, n. 1, p. 130-144, 2020.

\section{Contribuição de autoria}

Renata Farias de Felippe: concepção de estudo, preparação, redação e revisão do manuscrito, adequação da versão final para o aceite do artigo.

João Alcides Haetinger Esmerio: concepção de estudo, coleta e análise de dados, preparação e redação do manuscrito, análise e interpretação dos dados, adequação da versão final para o aceite do artigo. 


\section{Financiamento}

O presente trabalho foi realizado com apoio da Coordenação de Aperfeiçoamento de Pessoal de Nível Superior - Brasil (CAPES) - Código de Financiamento 001.

\section{Consentimento de uso de imagem}

Não se aplica.

\section{Aprovação de comitê de ética em pesquisa}

Não se aplica.

\section{Licença de uso}

Este artigo está licenciado sob a Licença Creative Commons CC-BY. Com essa licença você pode compartilhar, adaptar, criar para qualquer fim, desde que atribua a autoria da obra.

\section{Histórico}

Recebido em: 26/10/2019

Revisões requeridas em: 23/04/2020

Aprovado em: 29/04/2020 